\title{
最近の不動産関係判例の動き
}

\section{<私法 $>$}

概況

判時2250〜2259号, 判夕1411号〜1413号に登載 された注目すべき裁判例には, 土地所有者が土地 の譲渡により自ら作出した準袋地につき, 自動車 の通行を前提とした囲繞地通行権を肯定した事案 (高松高判平成26.4.23判時2251号60頁）等があっ た。今回は, 民法改正要綱案の論点の 1 つでもあ る「保証」に関する事案を紹介する。

東京高判平成25年 4 月 24 日（建物明渡請求控訴事件）, 控訴棄却・確定, 判夕 1412 号142頁

\section{【事案】}

(1)X (大田区) は, 平成12年 4 月 1 日， $\mathrm{Y}_{1}$ に対 し, $\mathrm{Y}_{2}$ の連带保証の下, 区営住宅を賃貸した。 平成14年11月, $\mathrm{Y}_{1}$ の子 $\mathrm{A}$ が, $\mathrm{X}$ の許可なく同居を 開始した。 $\mathrm{Y}_{1}$ は, 平成18年 2 月頃に本件住宅を 退去したが，Aはそのまま居住を続けた。

(2)そこで, Xは, 平成 18 年 3 月以降の使用料等 の滞納を理由に, 平成 22 年10月末で本件賃貸借契 約を解除したと主張し， $Y_{1}$ に対して賃貸借契約 に基づき, $\mathrm{Y}_{2}$ に対し連帯保証契約に基づき，解 除前の滞納使用料等の支払いを求めた。

(3)原審（東京地判平成24年 7 月18日判夕1412号 143頁）は，Y1に対する請求は全て認めたが， $\mathrm{Y}_{2}$ に対しては, 平成21年 3 月末までの滞納使用料等 のみ, $\mathrm{Y}_{1}$ と連帯して支払義務があり, それ以降 の請求は, 信義則に反し, 許されないとした。 $\mathrm{X}$ は,これを不服とし控訴した。

\section{【判旨】}

「賃借人の保証人に対する請求は一定の場合に は信義則により制限されることがある（最判平成 9 年11月13日判夕 969 号126頁参照)」。これを本件 に即してみると，原判決の判示するところ，すな わち, 「賃借人が賃料不払を続けながら賃貸建物 を明け渡さないという事態が生じた場合, 賃貸人
には，保証契約の当事者として，保証人の上記支 払債務が当該保証契約に即して通常想定されるよ りも著しく拡大する事態が生ずることを防止する ため, 当該保証人との関係で, 解除権等の賃貸人 としての権利を当該賃貸借の状況に応じて的確に 行使すべき信義則上の義務を負うというべきであ り, 当該賃貸人が当該権利の行使を著しく遅滞し たときは, 著しい遅滞状態となった時点以降の賃 料ないし賃料相当損害金の当該保証人に対する請 求は, 信義則に反し, 権利の濫用として許されな い」が相当である。

\section{【コメント】}

本判決は, 区営住宅の賃貸借契約の連帯保証人 に対する滞納使用料等の請求の一部が, 信義則に 反し権利濫用であるとした事案である。すでに, 類似判例として, 市営住宅の管理者が, 約10年分 の滞納家賃の支払いを連帯保証人に求めたが，連 帯保証人に対して賃料滞納の状況を一切知らせず 放置していたために本請求が権利濫用にあたると して棄却された事案等 (広島地福山支判平成20年 2 月 21 日裁判所ウェブサイト) がある。

具体的に信義則に反し権利濫用になる事情とし て, 本件では, 原審が説示した事情（1)Xは, 平 成18年 7 月の時点で, 本件住宅の $\mathrm{Y}_{1}$ の入居許可 の取消権が発生し, Aが不法占拠者であることを 認識していたこと, (2) $\mathrm{Y}_{1}$ がXの担当者に顛末を報 告し, AがXとの交渉に応じなかったことから， 平成19年 4 月以降は, $\mathrm{A}$ に対する明渡訴訟の提起 を検討すべきであったこと，(3)延滞使用料等が 2 年 1 カ月に及んでいた平成 20 年 3 月末の時点では, $\mathrm{Y}_{2}$ の保証債務額が拡大する事態を防止するため 速やかに訴訟を提起すべきであったこと, (4)にも かかわらず，訴訟を提起しなかったこと）に加え， (5)X生活福祉課が，Aに対する必要な住宅扶助を 支給して本件住宅の使用料等の滞納の発生を防止 
することが十分可能であったと解されること， (6) あえて $Y_{2}$ が附帯控訴しない応訴態度を示したこ とが挙げられている。このように，信義則違反及 び権利濫用を考える上で考慮される事実は何か, を具体的に示した点や，当事者及び関係者の法律 関係全体を考察の対象に加えて総合判断し, 慎重 に結論を導いている点は，今後の類似事案おける 判断材料として実務上も有用と考える。

(矢田尚子 日本大学法学部准教授)

\section{<公法 $>$}

概況

最近刊行の判例時報 2239 号〜 2255号, 判例夕イ ムズ1407号〜1410号における不動産関係判例のう ち, 公法系判例の中から, 北海道余市町の発注し た下水道工事により近隣住宅が傾斜したという住 民らの損害賠償請求控訴事件を紹介する。

札棍高判平成27年 2 月18日 (損害賠償請求控訴事件), 控訴棄却 (上告·上告受理申立て)，判時2255号82頁。

\section{【事案】}

北海道余市町の公共工事として行われた下水道 工事により，本件住宅が傾斜するなど不同沈下の 被害が生じたとして，主位的に国家賠償法 2 条 1 項に基づき余市町に対して，また，予備的に同法 1 条 1 項に基づいて同工事を共同事業体として施 行したA社，B社に対して，それぞれ共同不法行 為（民法719条）に基づき，本件住宅の物的損害 に関する損害賠償，遅延損害金の連帯支払をそれ ぞれに求めた事案である。原審は，下水道工事と 本件住宅に生じた変状との間には因果関係が認め られないと判断し, いずれも蓑却したため, 控訴 人らが控訴した。

\section{【判旨】}

控訴棄却。原判決の補正をするほか, 本件下水 道工事と本件建物の不同沈下の間に因果関係を認 めることができないから, 控訴人らの請求は, そ の余の点について検討するまでもなく理由がなく, いずれも棄却とするのが相当。

控訴人らは，本件建物について，工事完成から 約 2 力月後の平成 21 年 1 月 20 日から同年 2 月 10 日 にかけて行われた調査と, 同年 4 月17日に行われ た調査において，建物や工作物の亀裂等に特に変 化はないから, 同年 1 月 20 日以降は建物の不同沈
下は進行していない旨主張するが，上記の 2 ヶ月 から 3 ケ月の間に建物に特に変化がないことは, 本件建物が地盤の圧密沈下により長期間をかけて 徐々に不同沈下したことと矛盾しないから，上記 主張は失当である。さらに, 前者の調查時に撮影 された本件建物の基礎のひび割れ部分等の写真に よっても，長期間をかけてひび割れが発生したか そうでないかは判別できない。

\section{【コメント】}

ウイスキーで有名な余市町は, その地域の特徴 からも類推できるように, 河川があり莘が繁茂す る湿地帯があり，降雪で莘が十分に分解されずに 堆積するため, 軟弱地盤層が形成される。本件建 物の敷地も同様傾向であり, 建物の西側と東側で 堆積層の傾向が異なり, $\mathrm{N}$ 值が $0 \sim 5,9 \sim$ と いった軟弱地盤により非常に不安定な地盤の上に 建っている。

従来より, 地盤沈下の被害における損害賠償に ついては比較的良く見られる事案であるが, 行為 と損害の因果関係の立証が必要であり, 損害賠償 の請求者にその立証責任がある。立証の度合につ いては, 本来は自然科学的見地からの立証を示せ ば良いものの，その性質上立証が極めて困難であ ることから，最高裁判例（最二判昭和50年10月 24 日）によって，特定の事実が特定の結果発生を招 来した関係を是認しうる高度の蓋然性を証明すれ ば足りるとする考え方がとられている。とはいえ， 地盤沈下と建物との因果関係は不確実な要素が多 く，何を持って蓋然性といえるかについては必ず しも明確ではない。よって, 泣き寝入りの場合も ある。

本件の場合は公共下水道工事における家屋被害 を訴えるものであり, 蓋然性説で捉える事案では 本来は無いと考える。そもそも，その地域の地質 の自然的特性から軟弱地盤の存在は明らかであり, 工事実施のあり方として公共工事実施前後に周辺 住居等の家屋調査をすべきであると考える。丁寧 な作業によって，この種の紛争を未然防止するこ とが本来は大切である。家屋調査は民間開発行為 ではよく行われることであり，公共工事発注者で ある地方自治体の認識が問われるところである。

(本間 勝 明海大学不動産学部准教授) 